Article

\title{
First Insights into the Microbiome of a Mangrove Tree Reveal Significant Differences in Taxonomic and Functional Composition among Plant and Soil Compartments
}

\author{
Witoon Purahong ${ }^{1, *+\dagger} \mathbb{D}$, Dolaya Sadubsarn $1,2,+$, Benjawan Tanunchai ${ }^{1,+}$, \\ Sara Fareed Mohamed Wahdan ${ }^{1,3}$, Chakriya Sansupa ${ }^{1,4,5}$, Matthias Noll ${ }^{6}$, , Yu-Ting Wu ${ }^{\text {,* }}$ and \\ François Buscot 1,8 \\ 1 Department of Soil Ecology, UFZ-Helmholtz Centre for Environmental Research, 06120 Halle (Saale), \\ Germany; dolaya.sadubsarn@hs-furtwangen.de (D.S.); tanunchai.benjawan@ufz.de (B.T.); \\ sara-fareed-mohamed.wahdan@ufz.de (S.F.M.W.); chakriya.sansupa@gmail.com (C.S.); \\ francois.buscot@ufz.de (F.B.) \\ 2 Department of Bio and Process Engineering, Faculty of Medical Life and Science, Furtwangen University, \\ 78054 VS-Schwenningen, Germany \\ 3 Department of Botany, Faculty of Science, Suez Canal University, 41522 Ismailia, Egypt \\ 4 Biology Department, Faculty of Science, Chiang Mai University, Chiang Mai 50200, Thailand \\ 5 Graduate School, Chiang Mai University, Chiang Mai 50200, Thailand \\ 6 Institute for Bioanalysis, Coburg University of Applied Sciences and Arts, 96450 Coburg, Germany; \\ matthias.noll@hs-coburg.de \\ 7 Department of Forestry, National Pingtung University of Science and Technology, Pingtung 91201, Taiwan \\ 8 German Centre for Integrative Biodiversity Research (iDiv), 04103 Leipzig, Germany \\ * Correspondence: witoon.purahong@ufz.de (W.P.); yutingwu@mail.npust.edu.tw (Y.-T.W.) \\ + These authors contributed equally to this work.
}

Received: 18 September 2019; Accepted: 14 November 2019; Published: 20 November 2019

check for updates

\begin{abstract}
Mangrove forest trees play important ecological functions at the interface between terrestrial and marine ecosystems. However, despite playing crucial roles in plant health and productivity, there is little information on microbiomes of the tree species in mangrove ecosystems. Thus, in this study we aimed to characterize the microbiome in soil (rhizosphere) and plant (root, stem, and leaf endosphere) compartments of the widely distributed mangrove tree Rhizophora stylosa. Surprisingly, bacterial operational taxonomic units (OTUs) were only confidently detected in rhizosphere soil, while fungal OTUs were detected in all soil and plant compartments. The major detected bacterial phyla were affiliated to Proteobacteria, Actinobacteria, Planctomycetes, and Chloroflexi. Several nitrogen-fixing bacterial OTUs were detected, and the presence of nitrogen-fixing bacteria was confirmed by nifH gene based-PCR in all rhizosphere soil samples, indicating their involvement in $\mathrm{N}$ acquisition in the focal mangrove ecosystem. We detected taxonomically (54 families, 83 genera) and functionally diverse fungi in the R. stylosa mycobiome. Ascomycota (mainly Dothideomycetes, Eurotiomycetes, Sordariomycetes) were most diverse in the mycobiome, accounting for $86 \%$ of total detected fungal OTUs. We found significant differences in fungal taxonomic and functional community composition among the soil and plant compartments. We also detected significant differences in fungal OTU richness $(p<0.002)$ and community composition $(p<0.001)$ among plant compartments. The results provide the first information on the microbiome of rhizosphere soil to leaf compartments of mangrove trees and associated indications of ecological functions in mangrove ecosystems.
\end{abstract}

Keywords: bacterial diversity; fungal diversity; endophytic phytopathogens; fungal cenoses; halophytic plants; mangrove forest ecosystem; next-generation sequencing; plant epigeous compartments; Rhizophora stylosa microbiome 


\section{Introduction}

Mangrove forest ecosystems encompass genetically diverse communities at interfaces between terrestrial and marine ecosystems in many subtropical and tropical regions [1]. These transition ecosystems provide spawning and breeding grounds, nurseries, and habitats for many aquatic, semi-aquatic and terrestrial animals. Root systems of mangrove trees also provide natural barriers that reduce impacts of storms and protect coasts from erosion [2]. Moreover, mangrove forests are not only ecologically important but also economically valuable [2,3]. Many mangrove tree species are used for timber, fuelwood, and charcoal [2]. Mangrove forests are also rich sources of honey, and diverse medicinal, cosmetic, and other products [2,3]. In addition, they now attract many eco-tourists, anglers, and birdwatchers, thus contributing to incomes of countries with coastal mangroves [2,3]

Plants' microbiomes play crucial roles in their health and productivity [4]. Many researchers have successfully applied knowledge acquired about plant microbiomes to produce specific inocula for crop protection $[5,6]$. Such inocula can stimulate plant growth by releasing phytohormones and enhancing uptake of some mineral nutrients (particularly phosphorus and nitrogen) [6-8]. However, most of the plant microbiome studies have focused on the model plant Arabidopsis thaliana and economically important crop plants, such as barley (Hordeum vulgare), corn (Zea mays), soybean (Glycine max), rice (Oryza sativa), and wheat (Triticum aestivum), but there is less information on microbiomes of tree species $[4,6]$. Plant microbiomes are determined by plant-related factors (e.g., genotype, organ, species, and health status) and environmental factors (e.g., land use, climate, and nutrient availability) $[4,8]$. Two of the plant-related factors, plant species and genotypes, have been shown to play significant roles in shaping rhizosphere and plant microbiomes, as tree genotypes and species are associated with specific microbial communities [7]. Different plant organs also have specific microbial communities depending on plant-associated factors (plant genotype, available nutrients, and organ-specific physicochemical conditions) and/or environmental conditions (associated with aboveground and underground surfaces and disturbances) [9-11].

However, there is very limited information on microbiomes of tree species growing in mangrove forests, and most studies that have addressed them have focused on specific compartments of mangrove trees, such as rhizosphere, roots, or leaves [12,13]. Few have considered more than two compartments associated with different plant organs [10]. Thus, the inter-relationships of microbial communities in different plant compartments are still poorly understood.

To assist efforts to improve understanding, in this study we aimed to characterize the microbiome of the mangrove tree species Rhizophora stylosa, one of the most dominant species in widely distributed brackish environments across Asia and Australia [14]. The studied microbiome compartments included root, stem, and leaf endospheres, and the soil rhizosphere. We tested and/or quantified effects of soil and plant compartments (and selected physicochemical properties of plant compartments) on the richness and composition of bacterial and fungal communities, as well as the proportions (and taxonomic affiliations) of microbes capable of colonizing at least two compartments. We also explored potential ecological functions of microbes in the rhizosphere. We hypothesized that different compartments significantly differ in richness and composition of bacterial and fungal communities, and that these differences are related to differences in the compartments' physicochemical properties. For example, in mangrove ecosystems, salinity is high in rhizosphere soil and roots, but low in stems and leaves. We expected to detect differences in macronutrient contents among the compartments that affect the community composition of their microbiomes. We also hypothesized that some microbes can colonize more than one compartment, and some may even be detectable in all compartments from the rhizosphere to leaf. Such microbes must be adapted to both high and low salinity. Potential soil microbial ecological functions were characterized by measuring activities of important soil enzymes for the acquisition 
of macronutrients such as carbon ( $\mathrm{C} ; \beta$-glucosidase), nitrogen $(\mathrm{N} ; \mathrm{N}$-acetylglucosaminidase), and phosphorus (P; acid phosphatase) [15].

\section{Materials and Methods}

\subsection{Study Site, Experimental Design, and Sample Processing}

We selected five healthy, mature R. stylosa trees for sampling in spring (March) 2018. The trees were 170-200 cm tall, and growing in Zuo-An (Right Bank) wetland, located near a wastewater area in Pingtung County $\left(22^{\circ} 26^{\prime} 17.6^{\prime \prime}\right.$ N $120^{\circ} 29^{\prime} 29.6^{\prime \prime}$ E), southern Taiwan. Pingtung County has a tropical climate with an average annual rainfall of $1000 \mathrm{~mm}$ in coastal regions where the samples were taken, with minimum and maximum monthly temperature ranging from 14 to $25^{\circ} \mathrm{C}$ in January and 25 to $33^{\circ} \mathrm{C}$ in July [16]. Dominant mangrove trees in the Zuo-An wetland are R. stylosa, Kandelia candel, and Avicennia marina. Four compartments of the five selected trees and associated soil (root, stem and leaf endospheres and rhizosphere soil) were sampled, targeting two phylogenetic groups: bacteria and fungi. We sampled the stem wood using a Makita BDF 451 cordless drill equipped with a wood auger (diameter, $20 \mathrm{~mm}$ ), which was dipped into alcohol, flamed, and wiped with ethanol between drillings to avoid cross-contamination. The bark was completely removed from each selected part of a stem using a sterile knife before drilling. The drill was operated slowly and introduced perpendicularly to the stem axis at two positions (50 and $100 \mathrm{~cm}$ from the ground). The two stem samples were pooled to make a composite sample per tree. Eight leaves from three positions (top, middle, and bottom branches) per tree were also pooled to make a composite sample. In addition, four stilt root samples with rhizosphere soil from four directions around each tree were collected and pooled to make a composite sample. All samples were transported on ice to laboratory. Rhizosphere soil was removed by washing roots with molecular biology grade DNA-, RNAse-, and DNAse-free water (AppliChem, Darmstadt, Germany). Roots and leaves were then washed in Milli-Q water five times, $70 \%$ ethanol (for $7 \mathrm{~min}$ ) and Milli-Q water three times then placed in Milli-Q water for $1 \mathrm{~h}$ at room temperature. Each surface-sterilized root sample was subsampled, cut into small pieces ( $<2 \mathrm{~mm}$ long) using sterile scissors and then mixed with each other. Each surface-sterilized leaf sample was cut into small pieces $\left(<1 \mathrm{~cm}^{2}\right)$ using sterile scissors and ground into a fine powder using liquid nitrogen and a swing mill (Retsch, Haan, Germany).

\subsection{Soil Physicochemical Parameters}

Total carbon $(\mathrm{C})$ and nitrogen $(\mathrm{N})$ concentrations in rhizosphere soil and plant compartments were measured by dry combustion at $1000{ }^{\circ} \mathrm{C}$ with a CHNS-Elemental Analyzer (Elementar Analysensysteme $\mathrm{GmbH}$, Hanau, Germany). The $\mathrm{pH}$ and electric conductivity of rhizosphere soil samples were determined using a WTW Multi 3510 IDS portable meter (Weilheim, Germany). Cation ( $\mathrm{K}, \mathrm{Mg}$, Ca, and $\mathrm{Na}$ ) contents in plant compartments were determined by atomic absorption spectrophotometry, using a Z 5300 instrument following recommendations of the manufacturer (Hitachi-Science \& Technology, Tokyo, Japan).

\subsection{Analysis of Soil Rhizosphere Enzyme Activities}

To explore potential ecological functions in the rhizosphere of each individual tree, we analyzed activities of three important enzymes for $\mathrm{C}, \mathrm{N}$, and $\mathrm{P}$ acquisition- $\beta$-glucosidase (EC 3.2.1.21), $\mathrm{N}$-acetylglucosaminidase (EC 3.1.6.1), and acid phosphatase (EC 3.1.3.2), respectively-in the soil samples, using 4-methylumbelliferone (MUB) derivatives and previously described methodology [15]. To prepare soil slurries, $50 \mathrm{~mL}$ of $50 \mathrm{mM}$ sodium acetate buffer ( $\mathrm{pH}$ 5.5) were added to $0.5 \mathrm{~g}$ portions of soil (wet weight, equivalent to $0.098-0.183 \mathrm{~g}$ dry weight) and homogenized for $5 \mathrm{~min}$ in a bath sonicator. 4-MUB- $\beta$-glucopyranoside, 4-MUB-phosphate, and 4-MUB-N-acetyl- $\beta$-glucosaminide (150, 150 and $200 \mu \mathrm{mol} / \mathrm{L}$ ) substrate solutions were prepared for the $\beta$-glucosidase, acid phosphatase, and $\mathrm{N}$-acetylglucosaminidase assays, respectively. Substrate blank wells were filled with $50 \mu \mathrm{L}$ substrate 
solution and $200 \mu \mathrm{L}$ acetate buffer. Assay wells were filled with $50 \mu \mathrm{L}$ substrate solution and $200 \mu \mathrm{L}$ soil slurry. Quench coefficient and emission coefficient wells were filled with $50 \mu \mathrm{L}$ of a MUB dilution series $(2.5,1.25,0.625,0.16 \mu \mathrm{mol} / \mathrm{L})$ and $200 \mu \mathrm{L}$ soil slurry or $200 \mu \mathrm{L}$ acetate buffer. To prepare homogenized blanks, $200 \mu \mathrm{L}$ soil slurry and $50 \mu \mathrm{L}$ acetate buffer were mixed. Plate blanks were prepared by only adding $250 \mu \mathrm{L}$ acetate buffer. There were eight replicate wells for each substrate blank, assay, quench standard, emission standard, homogenate blank, and plate blank. The microplates were incubated in the dark at room temperature for $60 \mathrm{~min}$. To stop the reactions, $10 \mu \mathrm{L}$ of $1.0 \mathrm{M} \mathrm{NaOH}$ was added to each well approximately one minute before reading the plates. A FLUOstar OPTIMA microplate reader (BMG Labtech, Ortenberg, Germany) with $355 \mathrm{~nm}$ excitation and $460 \mathrm{~nm}$ emission filters was then used for measuring the fluorescence intensities of each well. After correcting for blanks, emission, and quenching, activities of the three enzymes were expressed in units of nmol h${ }^{-1} \mathrm{~g}_{\text {dry soil }}{ }^{-1}$.

\subsection{Microbiome Analysis}

DNA was extracted from approximately $150 \mathrm{mg}$ of each homogenized soil sample using a ZR Soil Microbe DNA MiniPrep kit (Zymo Research, Irvine, CA, USA) according to the manufacturer's protocol. The presence and quantity of genomic DNA were checked using a NanoDrop ND-1000 spectrophotometer (ThermoFisher Scientific, Dreieich, Germany). DNA extracts were then stored at $-20{ }^{\circ} \mathrm{C}$ for further analysis. Bacterial and fungal amplicon libraries were obtained separately for Illumina sequencing using the primer combination 341F (5'CCTACGGGNGGCWGCAG3') [17] and 785R (5'GACTACHVGGGTATCTAAKCC $3^{\prime}$ ) [17], which target the V3-V4 region of the 16S rRNA gene, as well as fITS7 (5'GTGARTCATCGAATCTTTG3') [18] and ITS4 (5'TCCTCCGCTTATTGATATGC3') [19], which target the fungal ITS2 region. PCR conditions are shown in the Supplementary Materials. Amplification products were visualized with eGels (Life Technologies, Grand Island, NY, USA). Products of three replicate reactions per sample were then pooled in equimolar amounts, and each pool was cleaned with a Diffinity RapidTip (Diffinity Genomics, West Henrietta, NY, USA), then sequenced using an Illumina MiSeq platform and V3 Chemistry (Illumina) by RTL Genomics (Lubbock, TX, USA). The presence of nitrogen-fixing bacteria in samples was verified by PCR using nifH gene-specific primers (PolF/PolR), as previously described [20].

\subsection{Bioinformatic Analysis}

The quality of reads from the paired-end sequences generated by the Illumina MiSeq sequencing platform was first examined using MOTHUR [21] and OBI tools software [22]. Reads fulfilling the following criteria were remained for further analyses: A minimum average quality of 25 Phred score; containing homopolymers with a maximum length of 20 nucleotides without ambiguous nucleotides. We detected chimeric sequences using the UCHIME algorithm, as implemented in MOTHUR and removed them from the datasets. The obtained reads were then clustered into operational taxonomic units (OTUs) using the CD-HIT-EST algorithm with a threshold of $97 \%$ sequence similarity [23]. The OTU representative sequences (defined as the most abundant sequence in each OTU) were taxonomically assigned by alignment with reference sequences in the SILVA 132 database for the bacterial 16S rRNA gene [24] and UNITE database (version unite.v7) [25] for fungal ITS, using the naive Bayesian classifier as implemented in MOTHUR with default parameters. They were also assigned to ecologically functional groups of bacteria and fungi using Functional Annotation of Prokaryotic Taxa (FAPROTAX) [26] and FUNGUILD [27], respectively. Rare OTUs (singletons to tripletons), which could potentially originate from artificial sequences, were removed. The read counts were normalized with respect to the smallest read number per sample (as detailed in the Results section). The raw sequence datasets are available in the National Center for Biotechnology Information database (NCBI) under the BioProject ID PRJNA554586. 


\subsection{Statistical Analysis}

The acquired data were analyzed using PAST software version 2.17c [28]. Measures of bacterial and fungal OTU richness, including Shannon diversity indices, were calculated using the PAST function "diversity indices". To assess the coverage (sequencing depth), data pertaining to each sample was subjected to rarefaction analysis using the PAST function "diversity" (Figure S1). Bacteria were only confidently detected in the rhizosphere compartment; thus, we did not perform further statistical analyses of effects of soil and plant compartments on their richness and community composition. Differences in fungal richness among the soil and plant compartments were analyzed using the Kruskal-Wallis (KW) test as their variances were not sufficiently homogenous for One-way ANOVA according to Levene's test. Data on the abundance of OTUs in the microbiome communities were converted to presence/absence data, as relative abundances derived from next-generation sequencing may be biased and should not be used for absolute quantification [29]. However, abundance data (numbers of sequencing reads) were used for heatmapping $\mathrm{N}$-fixing bacteria in rhizosphere soil samples. Percent occurrence data were used for heatmapping dominant fungi in all soil-plant compartments ( $\geq 80 \%$ in at least one compartment). Non-metric multidimensional scaling (NMDS) ordination based on presence/absence data and Jaccard distances in $\mathrm{R}$ (version 3.5.3) was used to investigate and visualize the composition of fungal communities in different soil and plant compartments. The Envfit function of the Vegan package in $\mathrm{R}$ was also used to investigate correlations between factors $(\mathrm{C}, \mathrm{N}$, $\mathrm{K}, \mathrm{Mg}, \mathrm{Ca}, \mathrm{Na}$ ) and the composition of the fungal communities (Table 1). The bacterial community in rhizosphere soil was subjected to corresponding NMDS and Envfit analyses. One-way analysis of similarities (ANOSIM) and nonparametric multivariate analysis of variance (NPMANOVA) were used to test the differences in fungal community composition among the soil and plant compartments using presence/absence data and Jaccard distances (Table 2). Significance levels were based on 999 permutations. As more than two groups were compared, Bonferroni-corrected $p$ values were applied. ANOSIM yields a sample statistic $(R)$ indicating the degree of separation between test groups, with values ranging from -1 to $1(R=0-0.24$, no separation to barely separated; $R=0.25-0.75$, separation with different degrees of overlap; $R>0.75-1$, well separated) [30]. Nutrients and their associated parameters were compared among the plant compartments using ANOVA. All datasets were tested for normality using the Jarque-Bera test and equality of variance using Levene's test. Data are presented as means and standard errors unless otherwise stated.

Table 1. Goodness-of-fit statistics $\left(R^{2}\right)$ for factors fitted to the non-metric multidimensional scaling (NMDS) ordination of fungal community composition of indicated plant compartments.

\begin{tabular}{ccccc}
\hline Variables & NMDS1 & NMDS2 & $\boldsymbol{R}^{\mathbf{2}}$ & $\boldsymbol{p}$ \\
\hline $\mathrm{N}$ & -0.24449 & -0.96965 & 0.3017 & 0.118 \\
$\mathrm{C}$ & 0.91384 & 0.40609 & 0.7252 & 0.002 \\
$\mathrm{C} / \mathrm{N}$ & 0.61409 & 0.78924 & 0.7074 & 0.002 \\
$\mathrm{Na}$ & -0.76628 & -0.64251 & 0.3764 & 0.049 \\
$\mathrm{~K}$ & -0.03703 & 0.99931 & 0.1363 & 0.465 \\
$\mathrm{Ca}$ & 0.80126 & 0.59831 & 0.5309 & 0.017 \\
$\mathrm{Mg}$ & -0.99599 & 0.08946 & 0.2532 & 0.176 \\
\hline
\end{tabular}


Table 2. Results of analysis of similarities (ANOSIM) and nonparametric multivariate analysis of variance (NPMANOVA) based on Jaccard distances and presence/absence data in comparisons of fungal community composition in indicated pairs of soil and plant compartments.

\begin{tabular}{ccc}
\hline Comparison & ANOSIM & NPMANOVA \\
\cline { 2 - 3 } & $\boldsymbol{R}$ & $\boldsymbol{F}$ \\
\hline Leaf vs. root & $0.64^{*}$ & $2.79^{*}$ \\
Leaf vs. rhizosphere soil & $1.00^{*}$ & $5.37^{*}$ \\
Leaf vs. stem & $0.84^{*}$ & $2.96^{*}$ \\
Root vs. rhizosphere soil & $0.79^{*}$ & $2.93^{*}$ \\
Root vs. stem & $0.79^{*}$ & $2.66^{*}$ \\
Rhizosphere soil vs. stem & $1.00^{*}$ & $4.09^{*}$ \\
\hline & $* p<0.05$. &
\end{tabular}

\section{Results}

\subsection{General Traits of the Microbiome Associated with the Mangrove Tree Rhizophora Stylosa}

Surprisingly, bacteria were only detected in all rhizosphere soil samples and only a few root endosphere samples. Despite testing various bacterial primer sets, only weak signals or no bacterial PCR products were obtained from root, stem, and leaf samples (Figure S2). Therefore, only rhizosphere soil samples were subjected to bacterial sequencing. In total, 66,263 sequences of bacterial 16S rRNA gene were detected in the rhizosphere soil samples, on average 13,252 \pm 187 per sample, after removing non-target and chimeric sequences. Singletons to tripletons were removed and the sequences were subsampled and rarefied to the smallest read numbers per sample (7086). Finally, 2497 different bacterial OTUs were obtained and used for further analyses. All the rarefaction curves indicated that the sampling effort was sufficient to capture each sample's overall composition (Figure S1). On average, OTU richness and chao- 1 estimated richness values of $1394 \pm 53$ and $1837 \pm 84$ were obtained for the five rhizosphere soil samples (Figure 1).

Fungi were detected in all soil and plant compartments. In total, 278,409 quality-filtered fungal ITS sequences were obtained from rhizosphere soil and plant compartment samples $(13,920 \pm 1734$ on average per sample) after removing non-target and chimeric sequences. Singletons to tripletons were removed and the sequences were subsampled and rarefied to the smallest read numbers per sample (7542). Finally, 455 fungal OTUs were obtained and used for further analyses. All the rarefaction curves indicated that the sampling effort was sufficient to capture each sample's overall composition (Figure S1). 

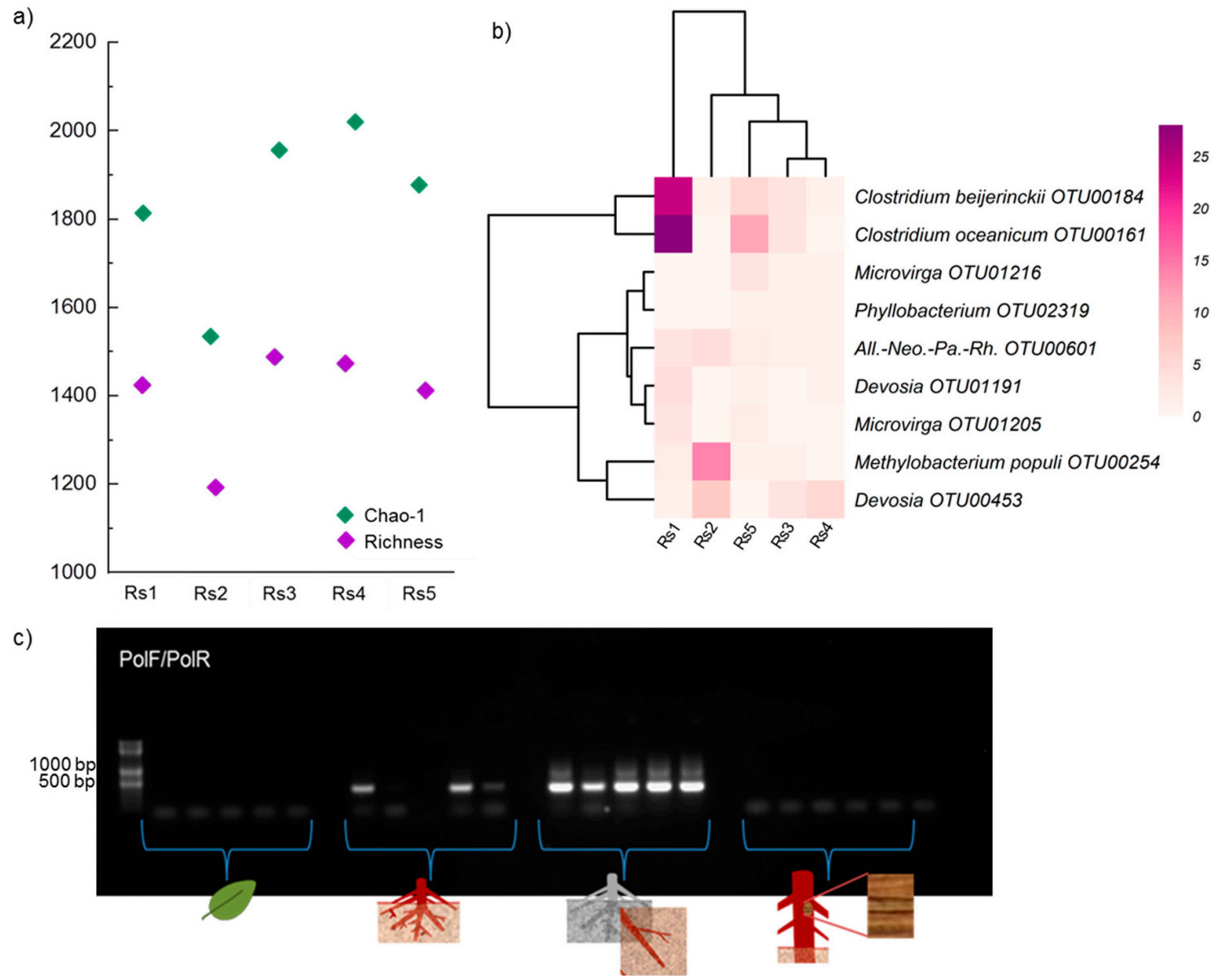

Figure 1. (a) Observed and Chao1-estimated richness of the bacterial microbiome in the five samples of rhizosphere soil (Rs1-Rs5), (b) heatmap of N-fixing bacteria (based on abundance data) in the samples, and (c) PCR results obtained using PolF/PolR primers to detect the nifH gene (360-bp) in the four soil and plant compartments (left to right: leaf, root, rhizosphere soil, and stem).

\subsection{Bacterial Community in Rhizosphere Soil}

Proteobacteria (856 OTUs), Actinobacteria (342 OTUs), Planctomycetes (358 OTUs), Chloroflexi (233 OTUs), and Firmicutes (161 OTUs) were the main bacterial taxa detected in the sampled soil of the R. stylosa rhizosphere (for details, see Supplementary Table S1). We successfully assigned 396/2497 bacterial OTUs into about 30 ecological functional groups (Figure S3). The frequently detected ecological functional groups ( $>2 \%$ of total functionally assigned OTUs) were aerobic chemoheterotrophy, sulfate respiration, fermentation, cyanobacteria, intracellular parasites, predatory, aromatic compound degradation, and nitrogen fixation (Supplementary Table S1, Figure S3). Sulfate respiration (122 OTUs, $31 \%$ of total functionally assigned OTUs) was mostly affiliated to Deltaproteobacteria (Desulfobulbaceae, Desulfobacteraceae, Desulfarculaceae, Syntrophaceae, Desulfohalobiaceae, Desulfuromonadaceae, and Desulfovibrionaceae). Nitrogen fixation was affiliated to nitrogen-fixing bacteria, like Allorhizobium-Neorhizobium-Pararhizobium-Rhizobium, Methylobacterium (Methylobacterium populi), Devosia, Microvirga, Phyllobacterium, and Clostridium (Figure 1). The presence of nitrogen-fixing bacteria was checked by nifH gene-based PCR using PolF/PolR primers (Figure 1c). The rhizosphere soil bacterial community was marginally significantly correlated with the $\mathrm{C} / \mathrm{N}$ ratio, but not other physicochemical properties (Figure 2, Supplementary Table S2). 

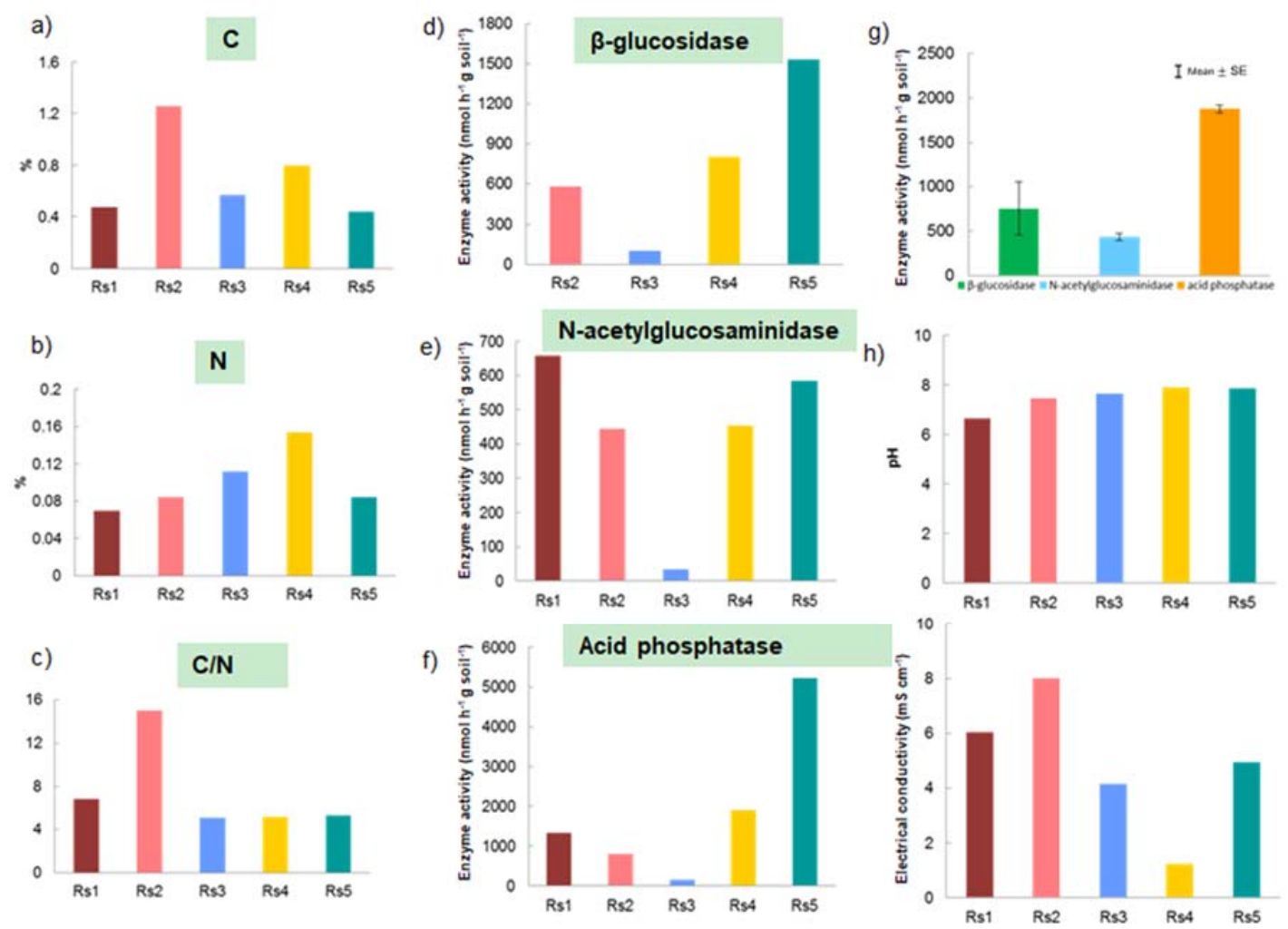

Figure 2. $(\mathbf{a}-\mathbf{c})$ Carbon content $(\mathrm{C})$, nitrogen content $(\mathrm{N})$ and carbon/nitrogen ratio $(\mathrm{C} / \mathrm{N})$; (d-f) $\beta$-glucosidase, $\mathrm{N}$-acetylglucosaminidase and acid phosphatase enzyme activities; (g) mean activity of $\beta$-glucosidase, $\mathrm{N}$-acetylglucosaminidase and acid phosphatase; (h) $\mathrm{pH}$; and (i) electrical conductivities in the five rhizosphere soil samples (Rs1-Rs5).

\subsection{Differences in Fungal Phylogenetic and Functional Community Composition among Soil and} Plant Compartments

Plant compartments differed in physicochemical properties, including carbon $(\mathrm{C})$ and nitrogen (N) contents, concentrations of major cationic nutrients $(\mathrm{K}, \mathrm{Mg}, \mathrm{Ca})$, and salinity (Na) (Figure 3, Supplementary Table S3). The leaf plant compartment had high N, C, Ca, and Mg contents. Stems and leaves had similar, high $\mathrm{C}$ content, $\mathrm{Ca}$ concentration, $\mathrm{C} / \mathrm{K}$ and $\mathrm{C} / \mathrm{Mg}$ ratios, but low Na concentration (Figure 3). The stem compartment had the highest $\mathrm{C} / \mathrm{N}$ and $\mathrm{C} / \mathrm{Mg}$ ratios (Figure 3). Roots had higher concentrations of $\mathrm{Na}$ and $\mathrm{Mg}$. Rhizosphere had much lower concentrations of both $\mathrm{C}$ and $\mathrm{N}$ than the other plant compartments (Figures 2 and 3). 
a)

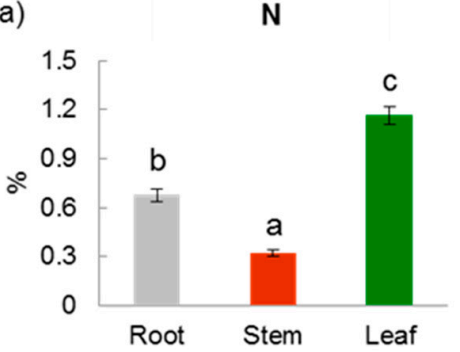

b)

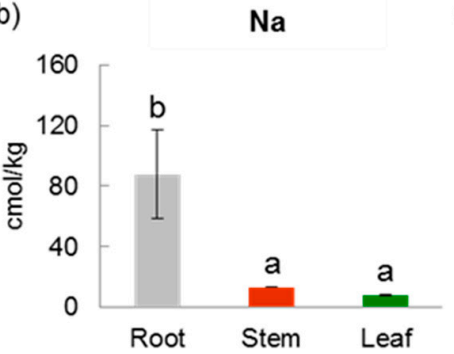

d)

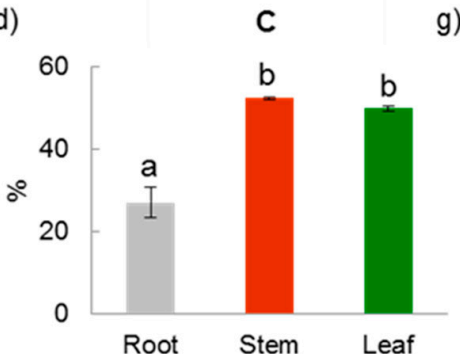

g)

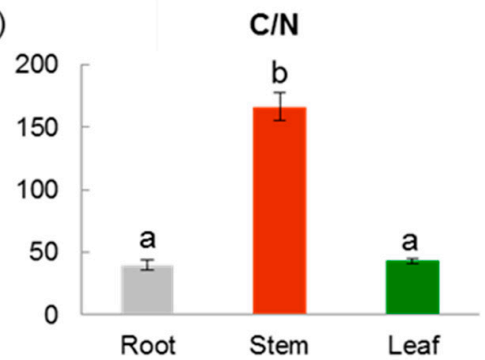

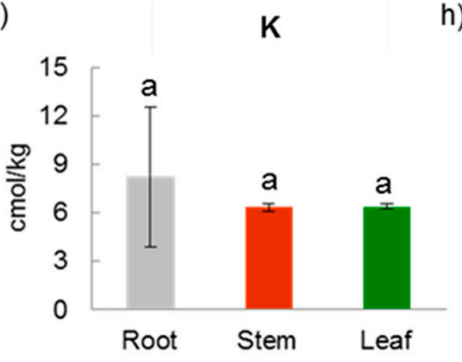

h)

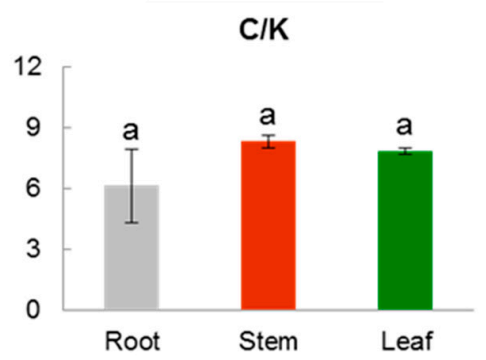

c)

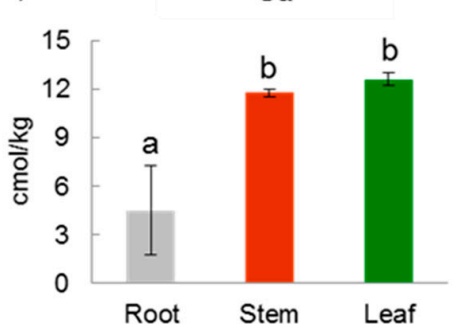

f)

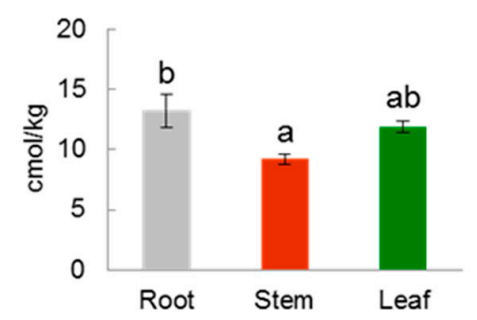

i)

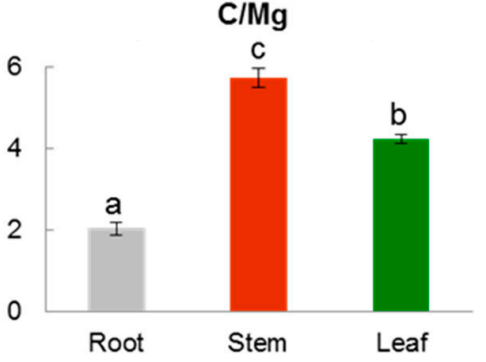

Figure 3. Measured values in root, stem, and leaf compartments of: (a) nitrogen (N), (b) sodium (Na), (c) calcium $(\mathrm{Ca}),(\mathbf{d})$ carbon $(\mathrm{C}),(\mathbf{e})$ potassium $(\mathrm{K}),(\mathbf{f})$ magnesium $(\mathrm{Mg})$ contents, $(\mathrm{g})$ carbon/nitrogen $(\mathrm{C} / \mathrm{N})$ ratio, $(\mathrm{h})$ carbon/potassium $(\mathrm{C} / \mathrm{K})$ ratio, and $(\mathbf{i})$ carbon/magnesium $(\mathrm{C} / \mathrm{Mg})$ ratio (means $\pm \mathrm{SE})$. Different letters above bars within panels indicate significant differences $(p<0.05)$ according to one-way analysis of variance (ANOVA).

Fungal communities differed between plant compartments (Figure 4). The major groups of fungi were Dothideomycetes (146 OTUs; including Cladosporium, Toxicocladosporium strelitziae, Hortaea werneckii, Phaeophleospora hymenocallidicola), Eurotiomycetes (125 OTUs; including Penicillium coffeae, Penicillium citrinum), and Sordariomycetes (76 OTUs; including Xylariaceae, Bartaliniaceae, Monosporascus). Dothideomycetes had the highest relative sequence abundance in every compartment and was dominant in stem and leaf compartments (accounting for $\geq 40 \%$ of total detected OTUs in them). In contrast, diversity of Eurotiomycetes was highest in the rhizosphere compartment (121 OTUs), but lowest in root (9 OTUs) and leaf (1 OTU) compartments. Similarly, the diversity of Sordariomycetes was highest in rhizosphere soil (68 OTUs), followed by root (12 OTUs), stem (7 OTUs), and leaf (1 OTU) compartments.

Affiliated functional guilds also varied across the compartments (Figure 4). We successfully assigned 134/455 fungal OTUs into about 11 functional guilds (Figure 4). Plant pathogens were the most abundant functional group detected in all compartments, but were particularly more frequently detected in stems and leaves (accounting for $\geq 50 \%$ of total functionally assigned OTUs detected in stem and leaf samples). Most OTUs in rhizosphere and root compartment corresponded to saprotrophs ( $\geq 35 \%$ of total functionally assigned OTUs detected in rhizosphere soil and root samples), which were barely detected in the stem samples and not detected at all in the leaf compartment. Plant pathogen-saprotrophs were moderately abundant in the rhizosphere soil and stem compartments (accounting for $\geq 15 \%$ of total functionally assigned OTUs detected in them), but were not detected 
in the leaf compartment. In turn, endophyte-plant pathogens were frequently detected in the leaf compartment ( $17 \%$ of total functionally assigned OTUs detected in leaf) but less frequently in the stem, root, and rhizosphere compartment (2 to $7 \%$ of total functionally assigned OTUs) (see Figure 4 ).

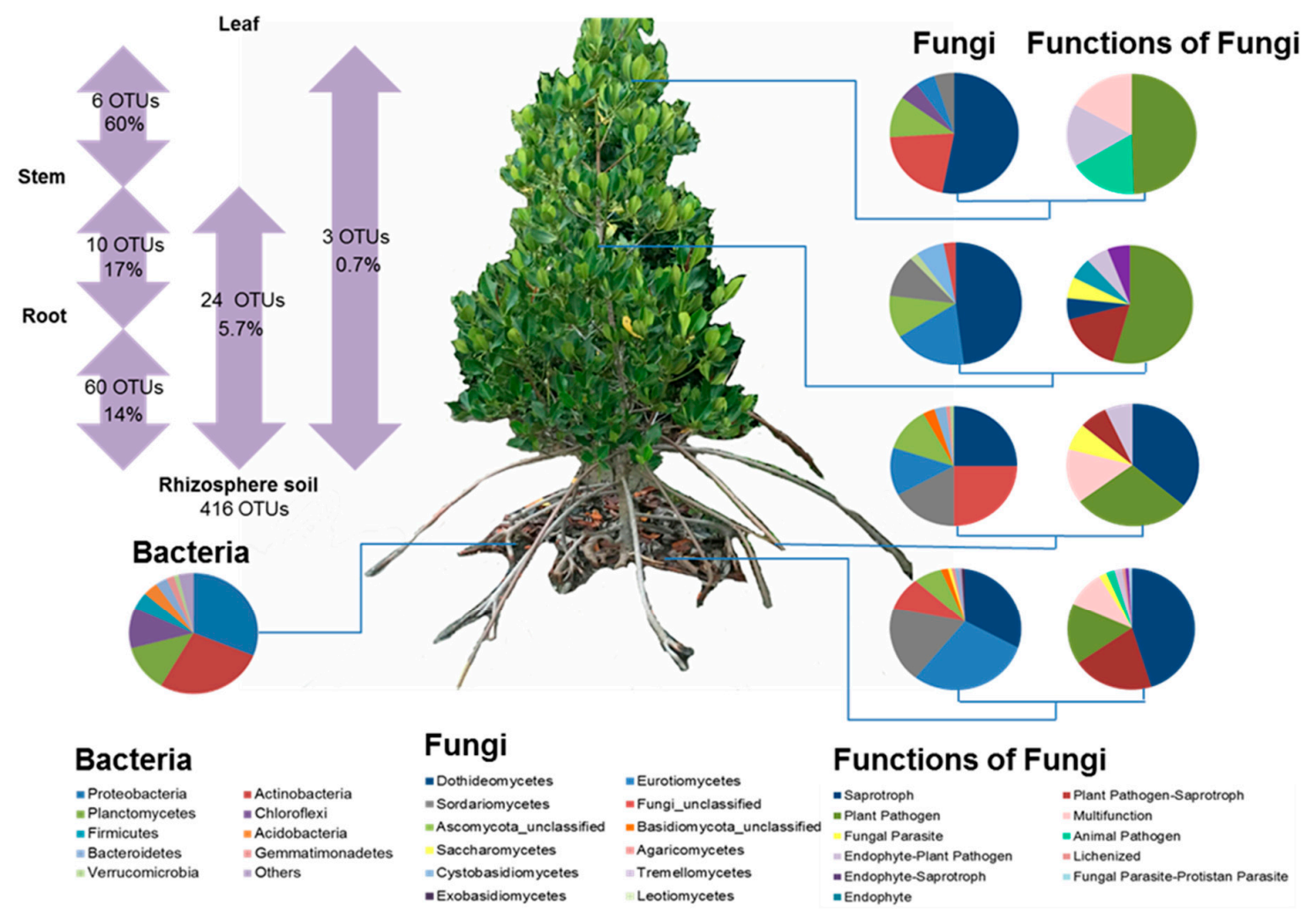

Figure 4. Bacterial taxonomic community composition in the rhizosphere soil and fungal taxonomic community composition in all four rhizosphere soil and plant compartments. Information on the fungal ecological functional groups is also provided. Proportions of fungal OTUs that can colonize at least two of the compartments are shown in the left panel.

\subsection{Effects of Plant Compartments on Microbial Richness}

Fungal OTU richness was significantly affected $(H=15.07, p=0.0017)$ by plant compartments (Figure 5). Rhizosphere soil samples had the highest richness (416 OTUs in total, $160.8 \pm 25.6$ on average), while leaves had the lowest richness (19 OTUs in total, $7.4 \pm 0.8$ on average). Fungal OTU richness in the root compartment (19 OTUs in total, $22.2 \pm 5.3$ on average) and stem compartment (61 OTUs in total, $21.0 \pm 3.5$ on average) were not significantly different. Observed and Chao1-estimated richness vales were consistent (Figure 5). 
a)

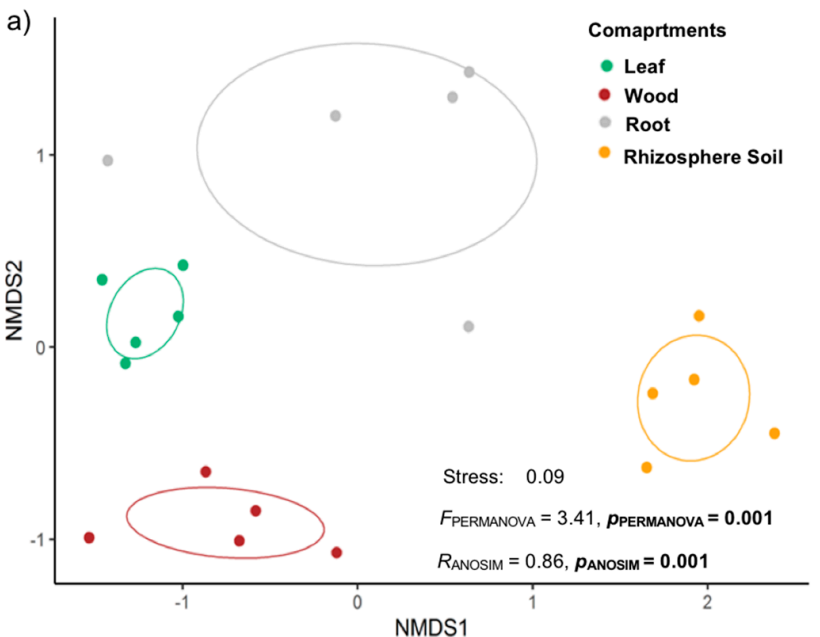

b)
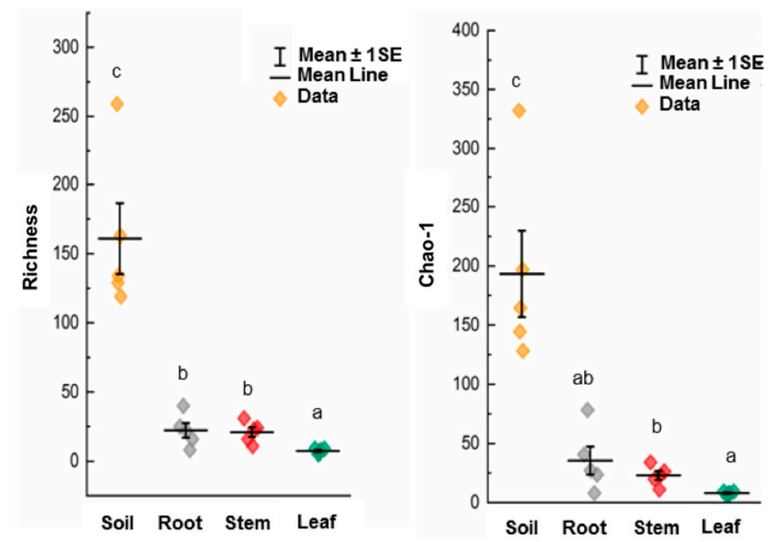

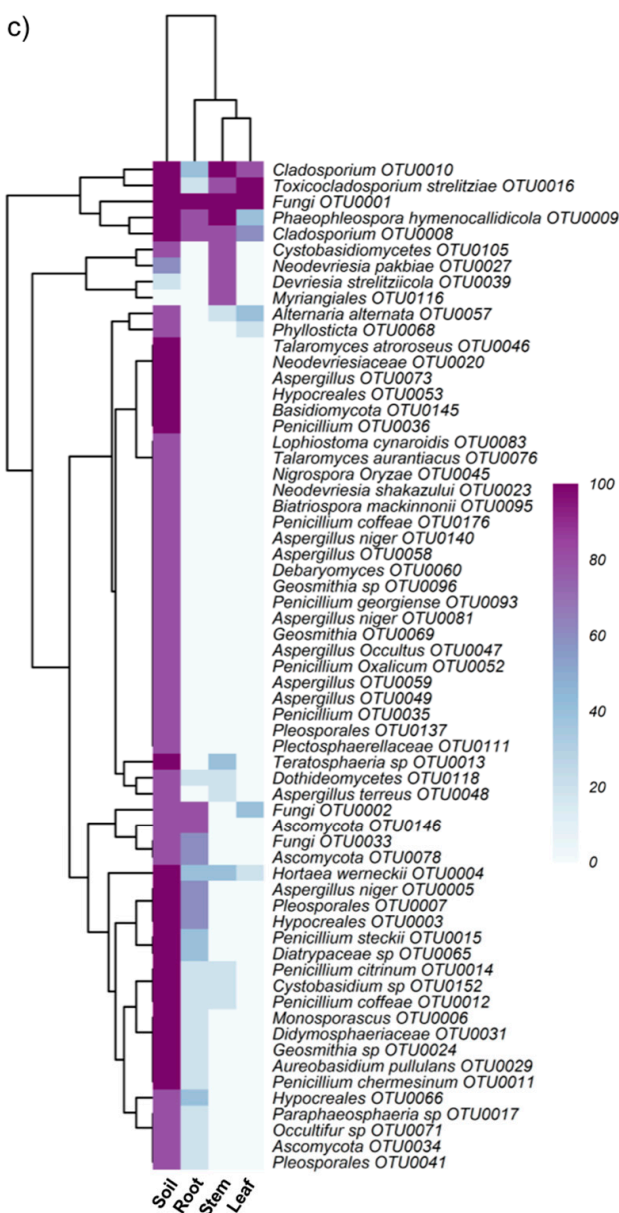

Figure 5. Fungal community composition and richness across the R. stylosa (rhizosphere soil and plant compartments: (a) non-metric multidimensional scaling plot of fungal communities in indicated compartments, showing 95\% confidence ellipses around mean values of NMDS axes 1 and 2; (b) fungal OTU and Chao1-estimated OTU richness (means \pm SE), and (c) heatmap of dominant fungal OTUs based on percent occurrence data (accounting for $\geq 80 \%$ of OTUs in at least one compartment). Different letters above OTU/Chao1 richness bars within a panel indicate significant differences $(p<0.05)$ according to analysis of variance or Kruskal-Wallis tests.

\subsection{Effects of Plant Compartments and Their Physicochemical Properties on Fungal Community Composition}

Fungal communities significantly differed among plant compartments $\left(F_{\mathrm{PERMANOVA}}=3.41\right.$, $\left.p=0.001, R_{\text {ANOSIM }}=0.86, p=0.001\right)$, and NMDS ordination clearly separated them in terms of community composition (Figure 5). In addition, $\mathrm{Na}, \mathrm{Ca}$, and $\mathrm{C}$ contents and $\mathrm{C} / \mathrm{N}$ ratio significantly correlated with the plant compartments' fungal community composition (Table 1), and both $\mathrm{C}$ content and $\mathrm{C} / \mathrm{N}$ ratio significantly correlated with the composition of the fungal communities of all soil and plant compartments (Supplementary Table S4).

\subsection{Microbes Capable of Colonizing At Least Two of the Soil-Plant Compartments}

A distinct fungal community composition was associated with each plant compartment (Figure 4). Proportions of the fungal class Dothideomycetes at OTU level were very high in leaf samples and gradually decreased in stem, root, and rhizosphere soil samples. In contrast, proportions of Eurotiomycetes were high in rhizosphere soil and gradually decreased in root, stem, and leaf samples. Proportions of the fungal class Agaricomycetes decreased from root through stem to leaf compartments. Two fungal classes (Tremellomycetes and Saccharomycetes) were detected only in the rhizosphere soil compartment. 
We analyzed distributions of each OTU that could colonize at least two compartments of rhizosphere soil and the internal plant tissues upwards from roots to leaves (and vice versa from leaves to rhizosphere soil) (Figure 4). Sixty fungal OTUs detected in rhizosphere soil (14\% of the total) were also detected in the root endosphere and thus could have been transported between these two compartments. Similarly, $17 \%$ of fungi detected in the root endosphere were also found in the stem compartment (10 OTUs), and 10\% of the fungi detected in the stem were also detected in the leaf endosphere compartment (six OTUs). In addition, $5.7 \%$ of rhizosphere soil fungi were detected in the stem, but not the root compartment (24 OTUs). Only $0.7 \%$ of the rhizosphere soil fungi were found in the leaves (three OTUs), but not the root and stem compartments. Overall, only six fungal OTUs (mainly plant pathogens) were detected in all soil-plant compartments. One of these (Otu0001) was an unclassified fungus, while the other five were assigned to the Dothideomycetes, and defined as Phaeophleospora hymenocallidicola (Otu0009, SH1209921.08FU), Hortaea werneckii (Otu0004, SH1154533.08FU), Toxicocladosporium strelitziae (Otu0016, SH1190879.08FU), and twice Cladosporium (Otu0008, Otu0010). Both Cladosporium OTUs were classified according to UNITE Species hypotheses as Mycosphaerella tassiana (SH1190878.08FU, current name Cladosporium herbarum).

\subsection{Potential Soil Microbial Ecological Functions}

Activities of the important enzymes for $\mathrm{C}, \mathrm{N}$, and $\mathrm{P}$ acquisition differed in the five rhizosphere soil (Rs) samples, declining in the order Rs5 $>$ Rs4 $>$ Rs1 $>$ Rs2 $>$ Rs3 (Figure 2). Acid phosphatase and $\beta$-glucosidase activities were highest in sample Rs5, while Rs3 had the lowest activities of these two enzymes (Figure 2). NAG activity was similar in all samples, except Rs3, which had the lowest activity. We investigated the rhizosphere microbial communities associated with Rs5 and Rs3 samples (which had the highest and lowest enzyme activities, respectively) and linked them with potential enzyme activities. Relative abundances of abundant bacteria were similar in Rs5 and Rs3 samples (Supplementary Table S5), but Rs5 had higher abundance of various fungi, including Aspergillus spp. (A. niger and A. flocculosus) and Penicillium spp. (P. steckii, P. coffeae and P. citrinum) than sample Rs3, especially A. niger (550 sequence reads in Rs5 vs. 88 in Rs3) (Supplementary Table S6).

\section{Discussion}

We provide the first information on mangrove tree microbiomes, encompassing root, stem and leaf endospheres and the rhizosphere. Furthermore, by showing that some fungi can colonize different plant compartments we contribute to disentangling their propagation channels within plants. Our results also reveal that fungi dominate the plant endosphere microbiome of healthy $R$. stylosa, which seems to be almost devoid of bacteria, at least at our study site. In this section, we compare and discuss the microbiome of $R$. stylosa and other model plants.

\subsection{Fungi Dominate Internal Microbiomes of R. stylosa}

Bacteria and fungi were both present in the rhizosphere, but only fungi were confidently detected in the internal plant compartments. It should be noted that although they are sometimes referred to as a subset of the rhizosphere microbiome, endophytic bacteria can greatly differ from rhizospheric bacteria [31], and many studies have shown that the majority of rhizospheric bacteria cannot invade intact plant tissues [31-33]. Accordingly, we only detected a few endogenous bacteria in the roots, and most rhizospheric bacteria were not detected in any endospheric compartment of $R$. stylosa. To exclude the possibility that groups of bacteria other than those of the rhizosphere might colonize several endospheric compartments, we tested several general bacterial primer pairs to detect endospheric bacteria of $R$. stylosa. However, we only obtained weak signals of PCR products of sequences associated with the 16S rRNA gene in some root, stem and leaf endosphere samples, suggesting that these plant compartments have very low bacterial biomass. The low bacterial biomass in leaves and other plant organs may be related to antibacterial agents produced by the plants [34]. Sources of such weak signals in the root endosphere may be nitrogen-fixing bacteria, as we detected the nifH gene in some DNA 
extracts of the root samples (Figure 1). Overall, our data suggest that fungi dominate the microbiomes in internal compartments of $R$. stylosa.

We found significant differences among internal compartments of $R$. stylosa in fungal community composition and richness, possibly linked to plant-associated and environmental factors [9,35]. Similar patterns have also been observed in other terrestrial and riparian woody plants in which the endospheric mycobiome was found to be compartment-specific [35,36]. In our study, the leaf endosphere compartment had lower richness of fungal OTUs ( 8 OTUs) than the other compartments. It should be noted that in a study of leaf-inhabiting fungi of $R$. stylosa in south China, Yao et al. (2019) found on average 57 OTUs, much more than we detected. This may reflect the strength of effects of location and environmental factors shaping fungal richness.

\subsection{Ascomycota Was the Most Frequently Detected Fungal Phylum}

The main fungal classes were Dothideomycetes, Eurotiomycetes, and Sordariomycetes-members of the Ascomycota that were detected in a previous study of epiphytic and endophytic fungi of mangrove tree species' leaves [13]. However, substantial proportions of fungi of the phylum Basidiomycota (Tremellomycetes, Microbotryomycetes, Exobasidiomycetes) in the endospheric leaf compartment of $R$. stylosa $(\sim 36 \%)$ were detected in the cited study [13]. We found only one OTU of Exobasidiomycetes (Sympodiomycopsis paphiopedili) and no members of the Tremellomycetes or Microbotryomycetes in the leaf endosphere compartment of $R$. stylosa, although the primers used were capable of amplifying such Basidiomycota sequence targets. Tremellomycetes were exclusively detected in rhizosphere soil. Other classes of Basidiomycota detected in our study are Cystobasidiomycetes and Agaricomycetes, which have also been detected in some previous studies of mangrove ecosystems [13,37].

\subsection{Factors Responsible for the Microbiome Speciation among Compartments of the Investigated Soil-Plant System}

The differentiation of plant microbiomes in different soil-plant compartments may be driven by niche-based processes (which require variation in local environmental conditions) [10], especially in cases such as this, where all the selected $R$. stylosa trees were located in the same ecosystem with less than $1 \mathrm{~km}$ between them and no visible dispersal barriers. There may be several reasons for the differences in microbiomes detected among the soil and plant compartments in our study [10]. First, there may be differences in local species pools that colonize each compartment, for example, the fresh and marine water and soil microbial pool for roots, and airborne and rainfall microbial pools for stems and leaves. Air- and rain-borne microbial pools can reach soil and potentially enter roots and other plant compartments, but in those compartments, they have to compete with existing soil microbial communities and be able to colonize the endosphere of root tissue. Second, there may be influential local biotic factors, for example, plants may promote establishment of beneficial, mutualistic microbes by secreting chemicals from specific organs that attract them. Third, abiotic factors may also be important, as different plant (and soil) compartments have different physicochemical properties (Figures 2 and 3). We found, for example, significant differences among plant organs in C content, $\mathrm{C} / \mathrm{N}$ ratio and $\mathrm{Ca}$ concentration that significantly correlated with their fungal community composition. The composition of the bacterial community at rhizosphere level also marginally correlated with $\mathrm{C} / \mathrm{N}$ values. These macronutrients $(\mathrm{C}, \mathrm{N}$ and $\mathrm{Ca}$ ) are highly relevant for microbial activity and growth $[38,39]$. $\mathrm{C}$ and $\mathrm{N}$ contents are sum parameters for cell activities [38,39]. $\mathrm{Ca}^{2+}$ is necessary for maintenance of cell structure, motility, and cell division, and affects the permeability of ions, sugar, and amino acids $[40,41]$. Thus, these macronutrients determine or partly shape the microbiome structure.

\subsection{Microbes in Extreme Environments: Na as a Factor Correlating with Microbial Community Composition}

Mangrove soils are typically saline, with moderate to high levels of $\mathrm{Na}$, which can also be transported to plant compartments especially by roots. Thus, the Na concentration was expected to be significantly correlated to microbial community composition. We confirmed this 
hypothesis, as we detected significant correlations between $\mathrm{Na}$ and fungal community composition. Electrical conductivity measurements of the rhizosphere soil compartment showed that it was mostly moderately saline. Moreover, high frequencies of halotolerant and halophilic microbes, such as Proteobacteria (genera Halomonas and Altererythrobacter), Actinobacteria (Isoptericola halotolerans), Firmicutes (Halobacillus trueperi and Bacillus jeotgali), and Bacteroidetes (Muricauda aquimarina) were found in the rhizosphere compartment. Many of these bacteria have been previously detected in saline soils [42]. Our sampling area is a wastewater area and we also frequently detected Caldilineaceae and sulfate reducing bacteria (Desulfobulbaceae, Desulfobacteraceae, Desulfarculaceae, Syntrophaceae, Desulfohalobiaceae, Desulfuromonadaceae, and Desulfovibrionaceae) (Supplementary Table S1 and Figure S3). Some studies have found some of these bacterial families in typical municipal wastewater treatment plants [43]. We also found halotolerant fungi, especially the yeast $H$. werneckii, a dominant black yeast species that can survive in hypersaline waters [44-46]. A. niger, which can also survive in hypersaline environments [47], was also frequently detected.

\subsection{Potential Soil Microbial Ecological Functions}

We detected considerable variation in activities of important enzymes for $\mathrm{C}, \mathrm{N}$, and $\mathrm{P}$ acquisition (especially acid phosphatase and $\beta$-glucosidase) among the samples of rhizospheric soil associated with different individuals of $R$. stylosa. We found higher relative sequence abundances of Aspergillus spp. (especially A. niger) and Penicillium spp. in samples with high acid phosphatase and $\beta$-glucosidase. These taxa might therefore contribute to production of these two enzymes. Previous studies have shown that $A$. niger can produce high amounts of both acid phosphatase and $\beta$-glucosidase $[48,49]$. Furthermore, Penicillium citrinum can reportedly produce high amounts of $\beta$-glucosidase [50]. Another interesting enzyme to test in the future is xylanase, which plays an important role in decomposition of hemicellulose [51]. This enzyme is reportedly produced by both bacteria (e.g., Bacillus spp.) [52] and fungi (Fusarium spp. and Aureobasidium spp.) [53] in mangrove ecosystems. These potential xylanase-producing microorganisms are detected in our study.

\subsection{Nitrogen-Fixing Bacteria in Rhizosphere soil}

Nitrogen plays important roles in plant growth, development, and health. Bacterial nitrogen fixation can be a significant source of nitrogen in mangrove ecosystems [54,55]. Members of the genera Rhizobium, Phyllobacterium, and Clostridium have been previously identified as nitrogen-fixing bacteria and found in the rhizosphere of mangrove ecosystems [56-59]. Some of the bacterial 16S rRNA gene sequences we identified were affiliated to known nitrogen-fixing bacteria in the rhizosphere (nine OTUs, representing six genera: Rhizobium, Methylobacterium, Devosia, Microvirga, Phyllobacterium, Clostridium), which were found in all rhizosphere samples (Figure 1). We also detected clear PCR amplicons of the nifH gene. Thus, we suggest that nitrogen-fixing bacteria may play an important role in nitrogen acquisition for $R$. stylosa. Interestingly, in this study we did not detect the globally distributed free-living nitrogen-fixing bacteria Azospirillum spp., which commonly occur in rhizospheres and roots of land-plants, including mangrove plant species $[60,61]$.

\subsection{Potential Transport of Pathogens}

Only few fungal phytopathogens find success in colonizing all soil-plant compartments, namely those which can be considered general plant pathogens are able to infect different plant districts. As we only investigated such fungi in the internal plant tissues of healthy looking trees (with no visible disease symptoms), the fungi we detected in all soil and plant compartments might be pathogens originating from soil that dwell in all internal plant tissues (root, stem and leaf) during the lifespan of $R$. stylosa. We propose that these plant pathogens could be transported by xylem (Supplementary Figure S4), as reported in other studies [62]. There are limited fungal plant pathogens, which thrive in this nutrient poor environment [62]. In this case, H. werneckii, T. strelitziae, P. hymenocallidicola can survive in this nutrient poor environment. H. werneckii is a halotolerant fungus that is involved in the 
formation of leaf lesions and non-pathological dermal change on human palms called tinea nigra [63]. T. strelitziae may cause minute brown lesions on flowers of Strelitzia reginae [64], and P. hymenocallidicola can cause leaf spot and tip blight disease on spider lily [65]. According to UNITE Species hypotheses Cladosporium Otu0008 and Otu0010 were both identified as M. tassiana (current name Cladosporium herbarum), which was detected in every plant compartment. It is known as a plant pathogen that can cause stigmatomycosis of Annona muricata [66]. Overall, our study provided evidence that some diseases associated with aboveground parts of plants in mangrove ecosystems may be caused by pathogens originating from belowground pools.

In summary, we detected few fungi spread over several compartments of $R$. stylosa, and as their frequencies in compartments did not change gradually or systematically, as in environmental gradients, there is low probability that fungi frequently move through the plant compartments from one to another. Furthermore, we find that the communities of each compartment are influenced by their specific physicochemical conditions, supporting the idea that tissues recruit their endogenous mycobiome largely independently.

\subsection{Comparison of the R. stylosa Microbiome to those of Other Model Plants in Different Ecosystems}

Rhizophora stylosa is a typical, important tree species of the mangrove ecosystem. Thus, the final goal of our work was to use R. stylosa as a model plant to investigate its microbiome and compare it to other model plants in other ecosystems [67], including: the general model plant Arabidopsis thaliana [68,69]; the model crop plants Oryza spp. (rice) [70,71] and Zea mays (maize) [72]; and the model forest tree genus Populus [10]. Overall, we found that the microbial communities of soil and plant compartments of $R$. stylosa had both unique and shared features with the other model plants. Shared features included: (i) rhizospheres have the highest bacterial and fungal richness [10,70], (ii) the endospheric bacterial community is frequently lower in leaves than in other plant organs [10,73], and (iii) the fungal communities in root and aboveground plant compartments are generally dominated by Ascomycota $[10,68]$. The unique features detected in $R$. stylosa compared to other model plants were as follows. First, fungi highly dominated the endosphere microbiome of all plant organs. In other model plants, both bacteria and fungi have been robustly detected in endospheres of plant organs, while the plants we examined were extreme in that we did not detect bacteria in endospheres of all their organs. Second, composition patterns of bacterial and fungal communities detected in the R. stylosa rhizosphere compartment differed from those of model plants reported in previous studies [10,69-72]. Generally, Proteobacteria, Acidobacteria, Actinobacteria form the backbone of the bacterial rhizosphere microbiomes in the model plants. However, we rarely detected Acidobacteria in the rhizosphere of R. stylosa (relative abundance $\sim 4 \%$ ). We also frequently detected Planctomycetes and Chloroflexi (relative abundance $>10 \%$ ). In some specific soil types and locations, these two bacterial phyla also reportedly co-dominate the rhizosphere of Oryza spp. [70,71]. Third, Dikarya (Ascomycota and Basidiomycota) were the only fungi detected in the rhizosphere and endospheres (root, stem and leaf) of R. stylosa, while other, lower fungi, such as Zygomycota and Chytridiomycota, etc. were apparently absent. In compartments of other model plants, both Dikarya and lower fungi have been detected. In Populus spp. and Oryza spp., lower fungi of the Zygomycota even co-dominate the rhizosphere and/or root (in Populus spp.) microbiomes [10,71]. Locations, soil types, and environmental factors also strongly affect the taxonomic composition of bacterial and fungal communities at coarse and fine taxonomic resolutions in these model plants [69,70,72-74]. Thus, similar microbiome studies of $R$. stylosa should be conducted in other locations with different environmental conditions to confirm if the unique pattern observed in our study is specific for this environment or is a general pattern for this tree species.

Supplementary Materials: The following are available online at http://www.mdpi.com/2076-2607/7/12/585/s1.

Author Contributions: Conceptualization, W.P., Y.-T.W. and F.B.; field sampling, W.P. and Y.-T.W.; enzyme analysis, W.P., B.T., S.F.M.W., M.N., C.S. and D.S.; chemical analysis, Y.-T.W. and B.T.; molecular analysis, B.T., D.S. and W.P.; bioinformatics, S.F.M.W., software, W.P.; formal analysis, W.P. and D.S.; investigation, W.P. and 
D.S.; resources, W.P. and Y.-T.W.; data curation, W.P. and D.S.; writing—original draft preparation, W.P. and D.S.; writing-review and comment, F.B., B.T., S.F.M.W., M.N., C.S., writing-editing and finalization, D.S., M.N., and W.P.; visualization, D.S.; supervision, W.P.; funding acquisition, W.P.

Funding: Our work was funded by the annual research fund of the Department of Soil Ecology, UFZ-Helmholtz Centre for Environmental Research.

Acknowledgments: We thank Sung, Ying-Ping Yang, Hsi-Ping Yeh, Sih-Yan Liao, Chen-Xiang Jiang, Jia-Hao Tien, I-No (students from the Department of Forestry, National Pingtung University of Science and Technology) for their help during sampling and sample processing.

Conflicts of Interest: The authors declare no conflict of interest.

\section{References}

1. Wen-jiao, Z.; Xiao-yong, C.; Peng, L. Accumulation and biological cycling of heavy metal elements in Rhizophora stylosa mangroves in Yingluo Bay, China. Mar. Ecol. Prog. Ser. 1997, 159, 293-301.

2. Salem, M.E.; Mercer, D.E. The economic value of mangroves: A meta-analysis. Sustainability 2012, 4, 359-383. [CrossRef]

3. Hecht, J.E. The Economic Value of the Environment; IUCN-The World Conservation Union: Gland, Switzerland, 1999.

4. Purahong, W.; Orrù, L.; Donati, I.; Perpetuini, G.; Cellini, A.; Lamontanara, A.; Michelotti, V.; Tacconi, G.; Spinelli, F. Plant microbiome and its link to plant health: Host species, organs and Pseudomonas syringae pv. actinidiae infection shaping bacterial phyllosphere communities of kiwifruit plants. Front. Plant Sci. 2018, 9, 1563. [CrossRef]

5. Afzal, A.; Bano, A. Rhizobium and phosphate solubilizing bacteria improve the yield and phosphorus uptake in wheat (Triticum aestivum). Int. J. Agric. Biol. 2008, 10, 85-88.

6. Busby, P.E.; Soman, C.; Wagner, M.R.; Friesen, M.L.; Kremer, J.; Bennett, A.; Morsy, M.; Eisen, J.A.; Leach, J.E.; Dangl, J.L. Research priorities for harnessing plant microbiomes in sustainable agriculture. PLoS Biol. 2017, 15, e2001793. [CrossRef]

7. Berendsen, R.L.; Pieterse, C.M.J.; Bakker, P.A.H.M. The rhizosphere microbiome and plant health. Trends Plant Sci. 2012, 17, 478-486. [CrossRef]

8. Bringel, F.; Couée, I. Pivotal roles of phyllosphere microorganisms at the interface between plant functioning and atmospheric trace gas dynamics. Front. Microbiol. 2015, 6, 486. [CrossRef]

9. Coleman-Derr, D.; Desgarennes, D.; Fonseca-Garcia, C.; Gross, S.; Clingenpeel, S.; Woyke, T.; North, G.; Visel, A.; Partida-Martinez, L.P.; Tringe, S.G. Plant compartment and biogeography affect microbiome composition in cultivated and native Agave species. New Phytol. 2016, 209, 798-811. [CrossRef]

10. Cregger, M.A.; Veach, A.M.; Yang, Z.K.; Crouch, M.J.; Vilgalys, R.; Tuskan, G.A.; Schadt, C.W. The Populus holobiont: Dissecting the effects of plant niches and genotype on the microbiome. Microbiome 2018, 6, 31. [CrossRef]

11. Hacquard, S. Disentangling the factors shaping microbiota composition across the plant holobiont. New Phytol. 2016, 209, 454-457. [CrossRef]

12. Wu, P.; Xiong, X.; Xu, Z.; Lu, C.; Cheng, H.; Lyu, X.; Zhang, J.; He, W.; Deng, W.; Lyu, Y.; et al. Bacterial communities in the rhizospheres of three mangrove tree species from Beilun Estuary, China. PLoS ONE 2016, 11, e0164082. [CrossRef] [PubMed]

13. Yao, H.; Sun, X.; He, C.; Maitra, P.; Li, X.-C.; Guo, L.-D. Phyllosphere epiphytic and endophytic fungal community and network structures differ in a tropical mangrove ecosystem. Microbiome 2019, 7, 57. [CrossRef] [PubMed]

14. Suwa, R.; Hagihara, A. Seasonal changes in canopy photosynthesis and foliage respiration in a Rhizophora stylosa stand at the northern limit of its natural distribution. Wetl. Ecol. Manag. 2008, 16, 313-321. [CrossRef]

15. Purahong, W.; Durka, W.; Fischer, M.; Dommert, S.; Schöps, R.; Buscot, F.; Wubet, T. Tree species, tree genotypes and tree genotypic diversity levels affect microbe-mediated soil ecosystem functions in a subtropical forest. Sci. Rep. 2016, 6, 36672. [CrossRef]

16. Yang, T.-H.; Yang, S.-C.; Ho, J.-Y.; Lin, G.-F.; Hwang, G.-D.; Lee, C.-S. Flash flood warnings using the ensemble precipitation forecasting technique: A case study on forecasting floods in Taiwan caused by typhoons. J. Hydrol. 2015, 520, 367-378. [CrossRef] 
17. Klindworth, A.; Pruesse, E.; Schweer, T.; Peplies, J.; Quast, C.; Horn, M.; Glöckner, F.O. Evaluation of general $16 \mathrm{~S}$ ribosomal RNA gene PCR primers for classical and next-generation sequencing-based diversity studies. Nucleic Acids Res. 2013, 41, e1. [CrossRef] [PubMed]

18. Ihrmark, K.; Bödeker, I.T.M.; Cruz-Martinez, K.; Friberg, H.; Kubartova, A.; Schenck, J.; Strid, Y.; Stenlid, J.; Brandström-Durling, M.; Clemmensen, K.E.; et al. New primers to amplify the fungal ITS2 region-evaluation by 454-sequencing of artificial and natural communities. FEMS Microbiol. Ecol. 2012, 82, 666-677. [CrossRef]

19. White, T.J.; Bruns, T.D.; Lee, S.; Taylor, J. Amplification and direct sequencing of fungal ribosomal RNA genes for phylogenetics. In PCR Protocols: A Guide to Methods and Applications; Innis, M.A., Gelfand, D.H., Sninsky, J.J., White, T.J., Eds.; Academic Press: San Diego, CA, USA, 1990; Volume 38, pp. 315-322.

20. Hoppe, B.; Kahl, T.; Karasch, P.; Wubet, T.; Bauhus, J.; Buscot, F.; Krüger, D. Network analysis reveals ecological links between N-fixing bacteria and wood-decaying fungi. PLoS ONE 2014, 9, e88141. [CrossRef]

21. Schloss, P.D.; Westcott, S.L.; Ryabin, T.; Hall, J.R.; Hartmann, M.; Hollister, E.B.; Lesniewski, R.A.; Oakley, B.B.; Parks, D.H.; Robinson, C.J.; et al. Introducing mothur: Open-source, platform-independent, community-supported software for describing and comparing microbial communities. Appl. Environ. Microbiol. 2009, 75, 7537-7541. [CrossRef]

22. Boyer, F.; Mercier, C.; Bonin, A.; Le Bras, Y.; Taberlet, P.; Coissac, E. Obitools: A unix-inspired software package for DNA metabarcoding. Mol. Ecol. Resour. 2016, 16, 176-182. [CrossRef]

23. Fu, L.; Niu, B.; Zhu, Z.; Wu, S.; Li, W. CD-HIT: Accelerated for clustering the next-generation sequencing data. Bioinformatics 2012, 28, 3150-3152. [CrossRef]

24. Quast, C.; Pruesse, E.; Yilmaz, P.; Gerken, J.; Schweer, T.; Yarza, P.; Peplies, J.; Glöckner, F.O. The SILVA ribosomal RNA gene database project: Improved data processing and web-based tools. Nucleic Acids Res. 2013, 41, D590-D596. [CrossRef]

25. Kõljalg, U.; Nilsson, R.H.; Abarenkov, K.; Tedersoo, L.; Taylor, A.F.S.; Bahram, M.; Bates, S.T.; Bruns, T.D.; Bengtsson-Palme, J.; Callaghan, T.M.; et al. Towards a unified paradigm for sequence-based identification of fungi. Mol. Ecol. 2013, 22, 5271-5277. [CrossRef] [PubMed]

26. Louca, S.; Parfrey, L.W.; Doebeli, M. Decoupling function and taxonomy in the global ocean microbiome. Science 2016, 353, 1272-1277. [CrossRef]

27. Nguyen, N.H.; Song, Z.; Bates, S.T.; Branco, S.; Tedersoo, L.; Menke, J.; Schilling, J.S.; Kennedy, P.G. FUNGuild: An open annotation tool for parsing fungal community datasets by ecological guild. Fungal Ecol. 2016, 20, 241-248. [CrossRef]

28. Hammer, Ø.; Harper, D.A.T.; Ryan, P.D. PAST: Paleontological statistics software package for education and data analysis. Palaeontol. Electron. 2001, 4,9.

29. Amend, A.S.; Seifert, K.A.; Bruns, T.D. Quantifying microbial communities with 454 pyrosequencing: Does read abundance count? Mol. Ecol. 2010, 19, 5555-5565. [CrossRef]

30. Purahong, W.; Wubet, T.; Krüger, D.; Buscot, F. Molecular evidence strongly supports deadwood-inhabiting fungi exhibiting unexpected tree species preferences in temperate forests. ISME J. 2018, 12, $289-295$. [CrossRef]

31. Turner, T.R.; James, E.K.; Poole, P.S. The plant microbiome. Genome Biol. 2013, 14, 209. [CrossRef]

32. Gottel, N.R.; Castro, H.F.; Kerley, M.; Yang, Z.; Pelletier, D.A.; Podar, M.; Karpinets, T.; Uberbacher, E.; Tuskan, G.A.; Vilgalys, R.; et al. Distinct microbial communities within the endosphere and rhizosphere of Populus deltoides roots across contrasting soil types. Appl. Environ. Microbiol. 2011, 77, 5934-5944. [CrossRef]

33. Hernández, M.; Dumont, M.G.; Yuan, Q.; Conrad, R. Different bacterial populations associated with the roots and rhizosphere of rice incorporate plant-derived carbon. Appl. Environ. Microbiol. 2015, 81, $2244-2253$. [CrossRef] [PubMed]

34. Semnani, S.N.; Hajizadeh, N.; Alizadeh, H. Antibacterial effects of aqueous and organic quince leaf extracts on gram-positive and gram-negative bacteria. Banats J. Biotechnol. 2017, 8, 54-61. [CrossRef]

35. Wearn, J.A.; Sutton, B.C.; Morley, N.J.; Gange, A.C. Species and organ specificity of fungal endophytes in herbaceous grassland plants. J. Ecol. 2012, 100, 1085-1092. [CrossRef]

36. Lau, M.K.; Arnold, A.E.; Johnson, N.C. Factors influencing communities of foliar fungal endophytes in riparian woody plants. Fungal Ecol. 2013, 6, 365-378. [CrossRef]

37. Loganathachetti, D.S.; Poosakkannu, A.; Muthuraman, S. Fungal community assemblage of different soil compartments in mangrove ecosystem. Sci. Rep. 2017, 7, 8560. [CrossRef] [PubMed] 
38. Gadd, G.M. Metals, minerals and microbes: Geomicrobiology and bioremediation. Microbiol. Read. Engl. 2010, 156, 609-643. [CrossRef]

39. Purahong, W.; Kapturska, D.; Pecyna, M.J.; Jariyavidyanont, K.; Kaunzner, J.; Juncheed, K.; Uengwetwanit, T.; Rudloff, R.; Schulz, E.; Hofrichter, M.; et al. Effects of forest management practices in temperate beech forests on bacterial and fungal communities involved in leaf litter degradation. Microb. Ecol. 2015, 69, 905-913. [CrossRef]

40. Dominguez, D.C. Calcium signalling in bacteria. Mol. Microbiol. 2004, 54, 291-297. [CrossRef]

41. Pitt, D.; Ugalde, U.O. Calcium in fungi. Plant Cell Environ. 1984, 7, 467-475. [CrossRef]

42. Ma, B.; Gong, J. A meta-analysis of the publicly available bacterial and archaeal sequence diversity in saline soils. World J. Microbiol. Biotechnol. 2013, 29, 2325-2334. [CrossRef]

43. Zhang, B.; Xu, X.; Zhu, L. Structure and function of the microbial consortia of activated sludge in typical municipal wastewater treatment plants in winter. Sci. Rep. 2017, 7, 17930. [CrossRef] [PubMed]

44. Cabañes, F.J.; Bragulat, M.R.; Castellá, G. Hortaea werneckii isolated from silicone scuba diving equipment in Spain. Med. Mycol. 2012, 50, 852-857. [CrossRef] [PubMed]

45. Gunde-Cimerman, N.; Ramos, J.; Plemenitaš, A. Halotolerant and halophilic fungi. Mycol. Res. 2009, 113, 1231-1241. [CrossRef] [PubMed]

46. Plemenitaš, A.; Vaupotič, T.; Lenassi, M.; Kogej, T.; Gunde-Cimerman, N. Adaptation of extremely halotolerant black yeast Hortaea werneckii to increased osmolarity: A molecular perspective at a glance. Stud. Mycol. 2008, 61, 67-75. [CrossRef]

47. Gunde-Cimerman, N.; Zalar, P. Extremely halotolerant and halophilic fungi inhabit brine in solar salterns around the globe. Food Technol. Biotechnol. 2014, 52, 170-179.

48. Hidayat, B.J.; Eriksen, N.T.; Wiebe, M.G. Acid phosphatase production by Aspergillus niger N402A in continuous flow culture. FEMS Microbiol. Lett. 2006, 254, 324-331. [CrossRef]

49. Lima, M.A.; Oliveira-Neto, M.; Kadowaki, M.A.S.; Rosseto, F.R.; Prates, E.T.; Squina, F.M.; Leme, A.F.P.; Skaf, M.S.; Polikarpov, I. Aspergillus niger $\beta$-glucosidase has a cellulase-like tadpole molecular shape: Insights into glycoside hydrolase family $3(\mathrm{GH} 3) \beta$-glucosidase structure and function. J. Biol. Chem. 2013, 288, 32991-33005. [CrossRef]

50. Ng, I.-S.; Li, C.-W.; Chan, S.-P.; Chir, J.-L.; Chen, P.T.; Tong, C.-G.; Yu, S.-M.; Ho, T.-H.D. High-level production of a thermoacidophilic $\beta$-glucosidase from Penicillium citrinum YS40-5 by solid-state fermentation with rice bran. Bioresour. Technol. 2010, 101, 1310-1317. [CrossRef]

51. Jasim, R.K. Isolation and molecular characterisation xylanase produced by Sporolactobacilli. Banats J. Biotechnol. 2016, 7, 30-37. [CrossRef]

52. Naresh, S.; Kunasundari, B.; Gunny, A.A.N.; Teoh, Y.P.; Shuit, S.H.; Ng, Q.H.; Hoo, P.Y. Isolation and partial characterisation of thermophilic cellulolytic bacteria from north Malaysian tropical mangrove soil. Trop. Life Sci. Res. 2019, 30, 123-147. [CrossRef]

53. Torres, J.M.O.; Dela Cruz, T.E.E. Production of xylanases by mangrove fungi from the Philippines and their application in enzymatic pretreatment of recycled paper pulps. World J. Microbiol. Biotechnol. 2013, 29, 645-655. [CrossRef] [PubMed]

54. Reef, R.; Feller, I.C.; Lovelock, C.E. Nutrition of mangroves. Tree Physiol. 2010, 30, 1148-1160. [CrossRef] [PubMed]

55. Holguin, G.; Vazquez, P.; Bashan, Y. The role of sediment microorganisms in the productivity, conservation, and rehabilitation of mangrove ecosystems: An overview. Biol. Fertil. Soils 2001, 33, 265-278. [CrossRef]

56. Cevallos, M.A.; Encarnación, S.; Leija, A.; Mora, Y.; Mora, J. Genetic and physiological characterization of a Rhizobium etli mutant strain unable to synthesize poly-beta-hydroxybutyrate. J. Bacteriol. 1996, 178, 1646-1654. [CrossRef] [PubMed]

57. Flores-Mireles, A.L.; Winans, S.C.; Holguin, G. Molecular characterization of diazotrophic and denitrifying bacteria associated with mangrove roots. Appl. Environ. Microbiol. 2007, 73, 7308-7321. [CrossRef]

58. Holguin, G.; Guzman, M.A.; Bashan, Y. Two new nitrogen-fixing bacteria from the rhizosphere of mangrove trees: Their isolation, identification and in vitro interaction with rhizosphere Staphylococcus sp. FEMS Microbiol. Lett. 1992, 101, 207-216. [CrossRef]

59. Sengupta, A.; Chaudhuri, S. Ecology of heterotrophic dinitrogen fixation in the rhizosphere of mangrove plant community at the Ganges river estuary in India. Oecologia 1991, 87, 560-564. [CrossRef] 
60. Hossain, M.M.; Jahan, I. Azospirillum as biofertilizer and Bangladesh perspective. Banats J. Biotechnol. 2015, 6, 69-82. [CrossRef]

61. Ravikumar, S.; Gnanadesigan, M.; Ignatiammal, S.T.M.; Sumaya, S. Population dynamics of free living, nitrogen fixing bacteria Azospirillum in Manakkudi mangrove ecosystem, India. J. Environ. Biol. 2012, 33, 597-602.

62. Yadeta, K.A.; Thomma, B.P.H.J. The xylem as battleground for plant hosts and vascular wilt pathogens. Front. Plant Sci. 2013, 4, 97. [CrossRef]

63. Petrovič, U.; Gunde-Cimerman, N.; Plemenitaš, A. Cellular responses to environmental salinity in the halophilic black yeast Hortaea werneckii. Mol. Microbiol. 2002, 45, 665-672. [CrossRef] [PubMed]

64. Crous, P.W.; Summerell, B.A.; Shivas, R.G.; Burgess, T.I.; Decock, C.A.; Dreyer, L.L.; Granke, L.L.; Guest, D.I.; Hardy, G.E.S.J.; Hausbeck, M.K.; et al. Fungal planet description sheets: 107-127. Persoonia Mol. Phylogeny Evol. Fungi 2012, 28, 138-182. [CrossRef]

65. Yi, R.H. Characterization of Phyllosticta hostae causing Phyllosticta leaf spot on spider lily in China. J. Plant Prot. Res. 2015, 55, 438-445. [CrossRef]

66. Thaung, M.M. Pathologic and taxonomic analysis of leaf spot and tar spot diseases in a tropical dry to wet monsoon ecosystem of lowland Burma. Australas. Plant Pathol. 2008, 37, 180-197. [CrossRef]

67. Van der Heijden, M.G.A.; Schlaeppi, K. Root surface as a frontier for plant microbiome research. Proc. Natl. Acad. Sci. USA 2015, 112, 2299-2300. [CrossRef] [PubMed]

68. Bergelson, J.; Mittelstrass, J.; Horton, M.W. Characterizing both bacteria and fungi improves understanding of the Arabidopsis root microbiome. Sci. Rep. 2019, 9, 1-11. [CrossRef]

69. Schlaeppi, K.; Dombrowski, N.; Oter, R.G.; Ver Loren van Themaat, E.; Schulze-Lefert, P. Quantitative divergence of the bacterial root microbiota in Arabidopsis thaliana relatives. Proc. Natl. Acad. Sci. USA 2014, 111, 585-592. [CrossRef]

70. Edwards, J.; Johnson, C.; Santos-Medellín, C.; Lurie, E.; Podishetty, N.K.; Bhatnagar, S.; Eisen, J.A.; Sundaresan, V. Structure, variation, and assembly of the root-associated microbiomes of rice. Proc. Natl. Acad. Sci. USA 2015, 112, E911-E920. [CrossRef]

71. Ding, L.-J.; Cui, H.-L.; Nie, S.-A.; Long, X.-E.; Duan, G.-L.; Zhu, Y.-G. Microbiomes inhabiting rice roots and rhizosphere. FEMS Microbiol. Ecol. 2019, 95, fiz040. [CrossRef]

72. Peiffer, J.A.; Spor, A.; Koren, O.; Jin, Z.; Tringe, S.G.; Dangl, J.L.; Buckler, E.S.; Ley, R.E. Diversity and heritability of the maize rhizosphere microbiome under field conditions. Proc. Natl. Acad. Sci. USA 2013, 110, 6548-6553. [CrossRef]

73. Bodenhausen, N.; Horton, M.W.; Bergelson, J. Bacterial communities associated with the leaves and the roots of Arabidopsis thaliana. PLoS ONE 2013, 8, e56329. [CrossRef] [PubMed]

74. Veach, A.M.; Morris, R.; Yip, D.Z.; Yang, Z.K.; Engle, N.L.; Cregger, M.A.; Tschaplinski, T.J.; Schadt, C.W. Rhizosphere microbiomes diverge among Populus trichocarpa plant-host genotypes and chemotypes, but it depends on soil origin. Microbiome 2019, 7, 76. [CrossRef] [PubMed]

(C) 2019 by the authors. Licensee MDPI, Basel, Switzerland. This article is an open access article distributed under the terms and conditions of the Creative Commons Attribution (CC BY) license (http://creativecommons.org/licenses/by/4.0/). 